\title{
Matter and energy flow in Spitsbergen ornithogenic tundra
}

\author{
ROMUALD Z. KLEKOWSKI AND KRZYSZTOF W. OPALIŃSKI
}

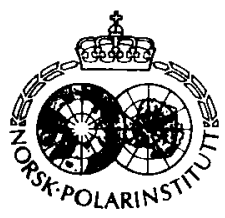

Klekowski, R. Z. \& Opaliński, K. W. 1986: Matter and energy flow in Spitsbergen ornithogenic tundra. Polar Research 4 n.s., 187-197.

Investigations were carried out on matter and energy flow through ornithogenic Spitsbergen tundra (Hornsund area, Vestspitsbergen, Svalbard). Data are given on the inflow and dispersion of nutrients in tundra, vegetation, distribution and primary production, organic matter destruction, microfauna abundance and its classification into trophic groups, and the metabolic rate of the dominant species of microfauna. It was found that in the ecosystem examined herbivorous invertebrates are almost lacking, the dominant food chain is detritus type, and the majority of the plant matter produced is removed beyond the system to the sea, in the form of detritus. A qualitative model of matter cycling in the ecosystem is given.

Romuald Z. Klekowski and Krzysztof W. Opaliniski, Department of Ecological Bioenergetics, Institute of Ecology, Polish Academy of Sciences, 05-092 Lominanki, Poland: February 1985 (revised June 1986).

The tundra regions cover about 6 million $\mathrm{km}^{2}$ (Sater et al. 1971), which form only 3 per cent of the total land area. However, due to the specificity of the tundra landscape, the section of the Terrestrial Communities of the International Biological Programme (IBP) has distinguished tundra as one of four main terrestrial biomes, along with deserts, meadows, and forests.

The exploration and exploitation of natural resources, mainly fuels, as well as tourism, have increased in polar regions and now form a serious threat to the existence of the tundra. The tundra is an ecosystem extremely vulnerable to any interference (see Wielgolaski 1972; Billings 1973), and the structure, function and regulation of tundra ecosystems should be investigated in order to minimize the effects of man on the natural environment in polar communities (Rosswall \& Heal 1975).

IBP did not investigate the Spitsbergen tundra, not only because it is small in size compared to the Alaskan tundra, the Canadian Arctics, and Siberia, but also because the Spitsbergen tundra has some untypical features. In the Svalbard Archipelago, which includes Spitsbergen, the tundra occurs exclusively in marine coastal zones, and it is richest on the coasts of fjords deeply cut into the land, especially in the region of Isfjorden. The poorest tundra, which gradually changes into arctic desert, is situated on the southern and eastern coasts of the archipelago. The cold East Spitsbergen Current passes these coasts.
The fauna of herbivores of the Spitsbergen tundra is very poor with only a few reindeer (Ragnifer tarandus plathyrhynchus), musk oxen imported from Greenland (Ovibos moschatus), ptarmigans (Lagopus mutus), and geese (Anser brachyrhynchus) inhabiting the region. In Spitsbergen there are no lemmings (Lemmus lemmus). The almost complete lack of herbivorous invertebrates is another typical feature of the Spitsbergen tundra, and they do not contribute to the energy flow (Remmert 1980). The invertebrate fauna is thus generally restricted to detritivores and predators.

The contact of the cold East Spitsbergen Current with the warm waters of the Gulf Stream along the coasts of Svalbard causes a prolific growth of plankton, and consequently, numbers of plankton feeders such as marine birds are found on these coasts. The birds build up their rookeries on rocks and in the tundra, and their faeces become an important local component of the tundra ecosystem (Remmert 1980).

The biological and ecological studies in Spitsbergen were mainly focused on the region of large fjords (Isfjorden), where the best conditions are found for the development of flora and fauna. The southern part of Spitsbergen southward from Bellsund, treated by Summerhayes and Elton (1928) as an arctic desert, has not been explored by biologists for a long time. Since the foundation of the Polish Station in Hornsund in 1957, biological and ecological investigations were started 
in southern Spitsbergen, especially in the Hornsund region. Polish biologists have played a considerable role in these studies, and the results have been used to make an inventory of the flora and fauna: Lichens (Nowak 1965, 1968), mosses (Kuc 1963; Karczmarz 1966, 1971; Karzcmarz \& Kuc 1966), flowering plants (Srodoń 1968), fungi (Skirgiełlo 1961, 1968), protozoans (Doroszewski 1958, 1959), Tardigrada (Weglarska 1966), Collembola (Stach 1962), Acarina (Niedbala 1971; Seniczak 1978; Seniczak \& Plichta 1978), Chironomidae larvae (Styczyński \& Rakusa-Suszczewski 1963; Rakusa-Suszczewski \& Styczyński 1968), birds (Ferens 1960; Birkenmajer \& Skreslet 1963; Stempniewicz 1981). These studies provided a static picture of the tundra, but they did not explain the function of tundra ecosystems.

The investigations presently carried out by the Institute of Ecology (PAS) in Spitsbergen aim to provide a quantitative recognition of the main pathways of matter and energy through the ornithogenic Spitsbergen tundra, and based on these data, a mathematical model of the functioning ecosystem will be constructed. The research covers a broad array of problems from terrain mapping for ecological needs (Mizerski in prep.), its geographical and physical characteristics (Krzyszowska et al. in prep.), water balance, hydrology, and hydrochemistry (Pulina in prep.; Krzyszowska in prep.), plant associations and productivity (Olech \& Dubiel in prep.; Opaliński in prep.), ecology and bioenergetics of terrestrial invertebrates (Klekowski \& Opaliński in prep. a, b, c; Opaliński \& Klekowski in prep. a, b), and birds (Stempniewicz in prep.) to models of a functioning tundra (Uchmański et al. in prep.).

The majority of the papers mentioned above have been completed and prepared for publishing. They will be issued in a special number of Polish Polar Research.

The present paper sums up the results obtained in the first stage of the field work carried out in the Hornsund region of Spitsbergen in 1980 and 1982. The results cited are derived from papers which are prepared for printing.

\section{The study area}

The area of coastal tundra in the south-western part of Spitsbergen (Vestspitsbergen, Svalbard) by the Hornsund fjord $\left(77^{\circ} 00^{\prime} \mathrm{N}, 15^{\circ} 00^{\prime} \mathrm{E}\right)$ was investigated. The study area is situated on the southern and south-western slopes of Fugleberget (569 $\mathrm{m}$ above sea level) and Ariekammen $(511 \mathrm{~m}$ a.s.1.) and reaches the sea through a series of sea terraces (Fig. 1). The hydrological system distinguishes the area as a quasi-closed and integrated system. The area is a microbasin, where waters in natural circulation form an isolated hydrological net with a common discharge to the sea. This area was given the working name the 'Fugleberget catchment' and has a surface area of $1.36 \mathrm{~km}^{2}$.

Summerhayes \& Elton (1923, 1928) have treated the whole of southern Spitsbergen as an arctic desert. However, some parts of the coast, especially deep in the fjords (e.g. the Hornsund Fjord) or the vicinity of bird colonies (e.g. Rålstranda), are covered with prolific tundra vegetation, mainly mosses and lichens. According to French's classification (1974) the tundra is of the 'cold oceanic' type.

In the region of the Hornsund and Fugleberget basin, the average temperature during the sum-

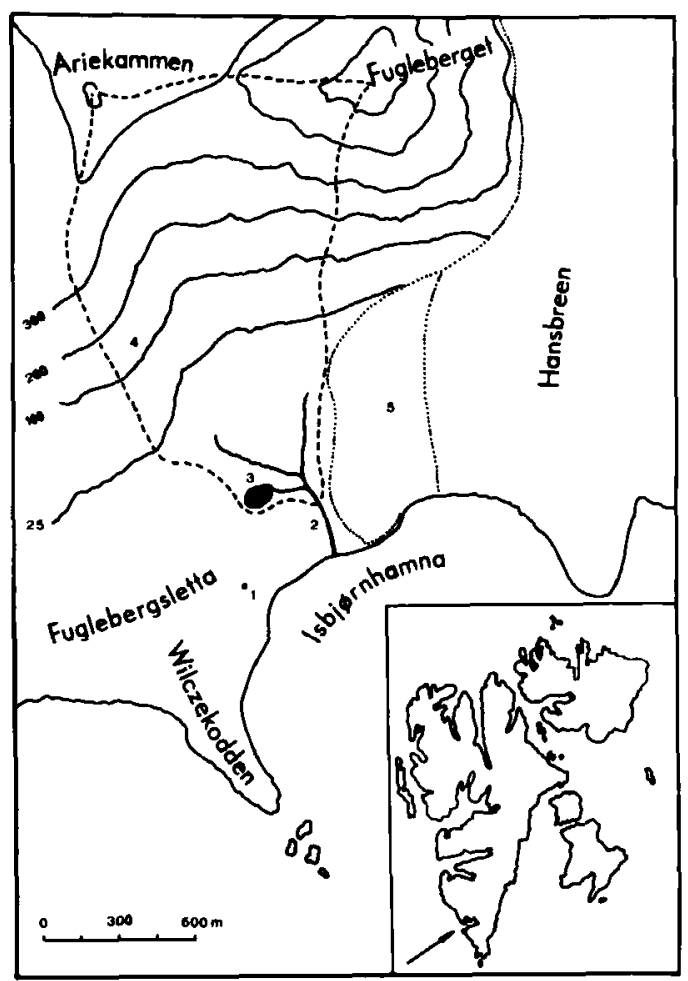

Fig. 1 . Sketch of the Fugleberget catchment area. Dashed line boundaries of the study area. 1. Polish Polar Station, Hornsund, 2. Fuglebekken river, 3. Water pool, 4. Little Auks rookery, 5. Hans Glacier moraine. Height in metres. 
mer months (June-August) is about $+2^{\circ} \mathrm{C}$ and during the winter months (September-May) about $-8^{\circ} \mathrm{C}$; the annual precipitation is about $350 \mathrm{~mm}$ (Baranowski 1975). The substrate consists of initial arctic soils - lithosols (Szerszeń 1965; Plichta 1977) - and there is little activity among the soil microflora (Zabawski \& Żurawska 1975). In the humid lower part of the basin (the first marine terrace, $15 \mathrm{~m}$ a.s.l.) mosses are predominant, and in the dry and higher reaches vascular plants and lichens are abundant. The distribution and species composition of flora on the Hornsund coast, including parts of the catchment area, are given by Kuc (1963), Nowak (1965, 1968), Srodoń (1968), Eurola (1968), and Eurola \& Hakala (1977).

Rookeries of little auk (Plautus alle) are situated in rock rubbles on the slopes of Ariekammen and Fugleberget at about $100 \mathrm{~m}$ a.s.l. The colony has an estimated 50,000 couples (Stępniewicz pers. comm.).

\section{Influx of allochthonous matter to the tundra}

Plautus alle inhabit the slopes of Ariekammen and Fugleberget from mid-June to mid-August. Here they build nests, mate, lay eggs (one by each couple), brood, and then feed the nestlings for about 27 days. During this period, the adults and nestlings of the colony consume about 280 tons of plankton (wet weight). About half of the faeces excreted by adults and all faeces produced by nestlings stay on land. The main load is deposited within the area of the nest colony, though some may be deposited in the tundra; 100 tons of faeces are deposited in total (estimates based on Norderhaug's data (1970) and on personal communication with Dr. L. Stempniewicz).

The main carrier of nutritional substances originating from bird faeces within the catchment area are surface running waters. These are mainly melt waters. In the late summer, periodical streams and brooks from thawing snow patches lingering in gullies and hollows in the higher regions of Fugleberget and Ariekammen feed into the catchment area. The annual surface water flow in the Fugleberget catchment area amounts to about $1 \times 10^{6} \mathrm{~m}^{3}$ (Krawczyk \& Pulina 1982; Pulina et al. in press; Pulina in prep.). The nutrient content of these waters varies at different locations in the catchment area and is also dependent on the prevailing weather conditions (intensity of water flow), and on the fenology of the auks. As an example, the concentration of nitratenitrogen in surface waters of the Fugleberget catchment area is about 0.1 to $33.5 \mathrm{mg} \mathrm{l}^{-1}$, nitritenitrogen varies from 0.001 to $0.020 \mathrm{mg} \mathrm{l}^{-1}$, and the phosphate content is between 0.02 and $2.20 \mathrm{mg} \mathrm{l}^{-1}$ (Krzyszowska in prep.). The highest concentrations of nutrients are observed in the immediate vicinity of the rookery, and the concentration of these substances decreases with increasing distance from the rookery (Fig. 2). This trend is most probably the result of the assimilation of nutrients by vegetation and also partly due to chemical and biochemical degradation (reduction of nitrogen compounds). In the rookery and in the whole catchment area guano deposits were not found, nor were minerals originating from substances found in faeces. This makes it different from Antarctic penguin rookeries, where there are guano deposits and layers of phosphates (struvite, hydroxylapatite, leucophosphite, and others, see Tatur \& Barczuk 1984). This lack of deposits in the Fugleberget catchment area would indicate that all nutrients supplied to the land are utilized by plants, or flows out of the system to the sea by the periodical stream Fuglebekken, which discharges into Isbjørnhamn Bay.

\section{Vegetation and primary production}

The constant inflow of organic matter and nutrients into the Fugleberget catchment area results in a relatively rich development of vegetation

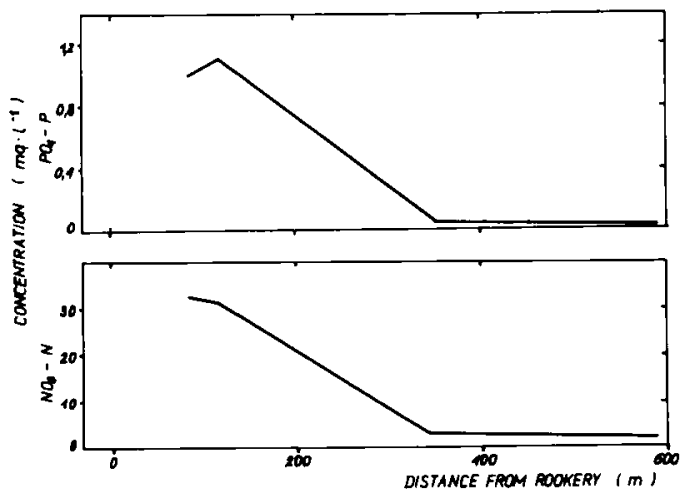

Fig. 2. Changes in $\mathrm{No}_{3}-\mathrm{N}$ and $\mathrm{PO}_{4}-\mathrm{P}$ concentrations in surface waters running off from Little Auks rookery in the Fugleberget catchment area (after Krzyszowska in prep.). 
compared with other tundra regions. Dominant species of flowering plants are Saxifraga oppsitifolia, $S$. cernuae, $S$. rivularis, Cerastium alpinum, Cochlearia officinalis, Oxyria digyna, Phippsia algida, Poa alpina var. vivipara, Chrysosplenium tetradarum, Draba alpina, Luzula confusa, and the only 'tree', the polar willow, Salix polaris. Information on flowering plants of the catchment area of Hornsund is given by Srodoń (1968), Fabiszewski (1967), Eurola (1968), Kuc (1968), Eurola \& Hakala (1977), and Olech \& Dubiel (in prep.).

Dominant moss species of the catchment area are: Calliergon stramineum, C. sarmentosum, Drepanocladus revolvens, Splachnum vasculosum, Hylocomnium splendens, Entodon schreiberi, Hygrohypnum polare, Messia triquetra, Manium regicum, Sphagnum squarrosum. A full description of mosses in the study area is provided by Kuc (1963).

Lichens occur in dry places and on rocks, and the following species are dominant within the area: Cladonia pyxidata, $\mathrm{Cl}$. rangiferina, Stereocaulon alpinum, Umbilicaria arctica, U. cylindrica, Cetraria crispa, C. islandica, Usnea sulphurea, Xanthoria elegans, Physcia muscigena, Caloplaca cinnamonea. Data on lichens in this area are given by Nowak $(1965,1968)$.

There are several types of plant/soil associations within the Fugleberget catchment area which are dependent on the differentiation of the substrate, the variation of water supply with dissolved nutrients, the amount of exposure to sun light, and other factors. The main types of plant/soil associations are listed in Table 1 . Lichens dominate the vegetation and occur on dry, elevated terrain and on rocks in the upper parts of Fugleberget and Ariekammen. This type of association covers $53 \%$ of the catchment area. The second largest association as measured by surface cover is the inundated moss meadows with polar willow, which cover $15 \%$ of the area. The smallest association is that of the dry mixed meadows on the rubble slopes in the proximity of the bird rookeries ( $2 \%$ of the area).

In the Fugleberget catchment area, especially adjacent to the bird rookeries, numerous species of phospho- and nitrophilous plants were observed, such as the alga Prasiola crispa, the lichens Caloplaca elegans and Physcia muscigena, the moss Splachnum vasculosum, and a number of vascular plants. In the vicinity of the rookery there are mainly vascular plants, which have a greater tolerance for high phosphorus concentrations than mosses (Eurola \& Hakala 1977).

The influx of nutrients to the tundra provides good conditions for the development of plants; plants are larger, more proliferous, they cover the soil to a greater extent, and their primary productivity is higher (Belopolsky 1957; Eurola \& Hakala 1977). The phenomenon of tundra plant stimulation by the influx of bird faeces has been

Table 1. Dominant plant communities in the Fugleberget catchment area.

\begin{tabular}{|c|c|c|c|c|c|}
\hline Plant community & $\begin{array}{l}\text { Dominant } \\
\text { plant type }\end{array}$ & $\begin{array}{l}\% \text { of area } \\
\text { covered } \\
\text { by plants }\end{array}$ & Ground type & $\begin{array}{l}\% \text { of catch- } \\
\text { ment area* }\end{array}$ & $\begin{array}{l}\text { Primary } \\
\text { production } \\
\text { (g dry wt } \\
\mathrm{m}^{-2} \text { year }^{-1} \text { ) }\end{array}$ \\
\hline Wet moss meadow & mosses & 100 & inactive polygons & 6 & $270^{* *}$ \\
\hline Dry mixed meadow & $\begin{array}{l}\text { mosses, vascular } \\
\text { plants }\end{array}$ & $80-100$ & rubble on slopes & 2 & $220^{* *}$ \\
\hline Dry meadow & vascular plants & 90 & rubble on slopes & 8 & $250^{* *}$ \\
\hline $\begin{array}{l}\text { Moss and lichen } \\
\text { meadow }\end{array}$ & $\begin{array}{l}\text { mosses and } \\
\text { lichens }\end{array}$ & $50-100$ & $\begin{array}{l}\text { rubble on uplifted } \\
\text { terrace edges }\end{array}$ & 6 & $50^{* * *}$ \\
\hline Polygonal tundra & vascular plants & $10-70$ & active polygons & 10 & $25^{* * *}$ \\
\hline $\begin{array}{l}\text { Inundated meadow with } \\
\text { Polar Willow }\end{array}$ & $\begin{array}{l}\text { mosses, vascular } \\
\text { plants with } \\
\text { Salix polaris }\end{array}$ & $40-80$ & talus cones & 15 & $25^{* * *}$ \\
\hline Lichens communities & lichens & $0-80$ & $\begin{array}{l}\text { peak rocks, rubble } \\
\text { on slopes }\end{array}$ & 53 & $2^{* * *}$ \\
\hline
\end{tabular}

- Total area of the Fugleberget catchment area is $1.36 \mathrm{~km}^{2}$

** measured value

*** approximate value 


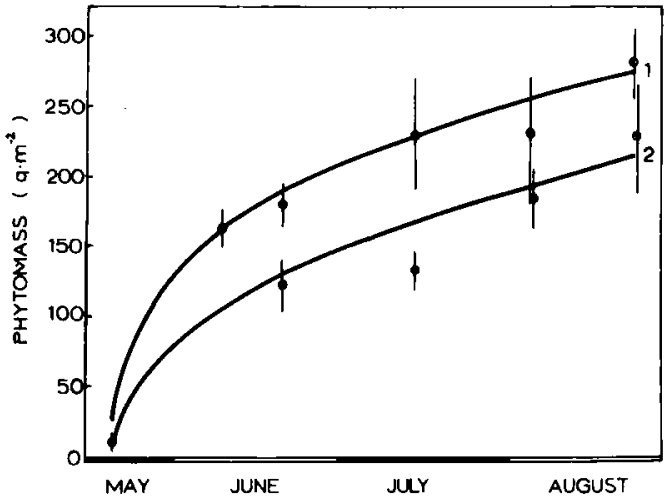

Fig. 3. Seasonal progression of the mean standing crops of dry weight of mosses in the Fugleberget catchment area: 1. Calliergon stramineum, 2. Splachnum vasculosum. Standard crrors of mean are added (after Opaliński in prep.).

termed the 'ornithocoprophilous influence' by Eurola \& Hakala (1977).

The primary production of moss and vascular plant communities in the Fugleberget catchment area is 270 and $240 \mathrm{~g}$ dry weight per year per $\mathrm{m}^{2}$ respectively (Opaliński in prep.) (Fig. 3). The values of the primary production in polar regions are usually lower; for moss communities from 100 to $150 \mathrm{~g} \mathrm{~m}^{-2}$ year $^{-1}$ (Bliss 1975; Bunnell et al. 1975; Eurola \& Hakala 1977) and for vascular plant communities from 35 to $100 \mathrm{~g} \mathrm{~m}^{-2}$ year $^{-1}$ (Tieszen 1972; Matveeva et al. 1975; Eurola \& Hakala 1977). The primary production is higher only in places fertilized by the influx of allochthonous organic matter (Rüppell 1968; Bliss 1975; Brzoska 1976).

\section{Destruction and decomposition}

Since there are few herbivores in the tundra of the Fugleberget catchment area, the whole green plant mass produced during the summer dies down in the winter and its degradation begins. In the case of mosses, during the first year of degradation, about 30 to $45 \%$ of the weight of dead moss is lost, and 55 to $70 \%$ of the weight degrades during the first four years (Fig. 4). After a further 10 years, no further weight loss is observed, and hence, after 13 years, about $25 \%$ of the initial weight is preserved (Opaliński in prep.).

The weight loss of dead moss has primarily a mechanical character, as opposed to the biological one of decomposition, which can be inferred from the nearly constant elementary composition of dead plant matter, especially of the carbon-nitrogen ratio (variation of the ratio is between 22 and 37, see Opaliński in prep.), and the positive correlation of the concentration of carbon and nitrogen. The latter indicates a low microbiological activity and microbial decomposition is presumed to be very weak. Hence, the loss of dead plant matter in the catchment area is mainly the result of mechanical destruction and partitioning from thermo-erosive processes, frost, and solifluxive movement. The limited growth of the soil microflora is caused by permafrost and by the poor development of arctic soils (Svensson \& Rosswall 1980).

In the literature on the subject there is little information regarding the degradation and decomposition rates of organic matter in the tundra; e.g. by the method of 'litter bags' the rate of weight loss estimates range from $1.3 \%$ (Baker 1972) to $19 \%$ (Bliss et al. 1973).

In many cases the inflow of allochthonous organic matter (bird faeces) to the tundra and other subpolar ecosystems brings about a development of proliferous vegetation and also the formation of specific types of soils rich in organic matter and nutrients - viz. ornithogenic soils (Syroechkovsky 1958). However, in Spitsbergen such effects are not found; the inflow of allochthonous matter and autochthonic dead plant matter does not enrich the soils, and the microbial activity is low.

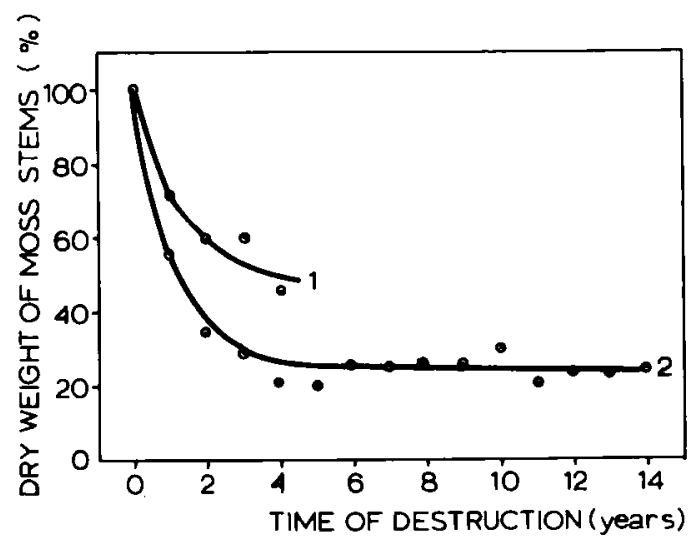

Fig. 4. Annual destruction rate of Calliergon stramineum (1) and Splachnum vasculosum (2) in the Fugleberget catchment area (after Opaliński in prep.). 


\section{Tundra microfauna - abundance and trophy}

The invertebrate fauna of the tundra in the Hornsund region and in the Fugleberget catchment area is very poor and consists of protozoans, nematodes, Tardigrada, Rotatoria, Apterygota Collembola, Coleoptera (which are only rarely found), Chironomidae larvae, Diptera, Cladocera (Daphnia), Acarina, Aranea, and Enchytraeidea. The fauna of the Hornsund region is limited compared with other parts of Spitsbergen, e.g. Isfjorden. According to Summerhayes \& Elton (1928), there are favourable conditions for the flora and fauna in a zone round Isfjorden, and 3 species of Aphidae, 2 or 3 species of Diptera, 3 species of Coleoptera, and 1 species of Lepidoptera were found here (Remmert 1980). In comparison with other tundra regions situated at the same latitudes in the Arctic, the invertebrate fauna of Spitsbergen is very poor; e.g. in Prudhoe Bay (Alaska) there are 37 species of Diptera, and 12 species of Lepidoptera (Brown 1975), and in Greenland 46 species of Crustacea (Røen 1962).

In the interstitial waters of moss swards and in the tundra lakes situated above Hornsund a number of protozoan species can be found: Nassula aurea, Dileptus cygnus, Colpoda cucullus, Stentor multiformis, Paramecium arcticum (Doroszewski 1959). Among the nematodes the following are predominant: Plectus parietinus, $P$. cirratus, Anoplectus porosus, Eudorylaimus carteri, and E. maksymowi (determined by $\mathrm{Dr}$. L. Wasilewska, Institute of Ecology, Polish Academy of Science). The most numerous rotifer is Macrotrachela musculosa. Trichotria truncata is somewhat rarer (determined by Prof. H. Klimowicz, Institute of Environmental Protection, Warsaw). The following Tardigrada species are predominant: Doryphoribius smreczynskii, Diaphascon spitsbergensis, Macrobiotus islandicus, $M$. echinogenitus, $M$. dispar, and $M$. spectabilis (determined by Dr. H. Dastych, Adam Mickiewicz University, Poznan, Poland). A full list of Tardigrada species occurring in the Hornsund region is given by Weglarska (1966).

There are a few fresh water crustaceans in the tundra above Hornsund. Daphnia pulex middendorfiana occurs in the periodical streams and Euphyllopoda occurs in small lakes with a muddy bottom, though the latter was not found in the Fugleberget catchment area.
Tundra insects have the largest biomass in the Fugleberget catchment area, and in the whole of Spitsbergen apterygous insects - Collembola are dominant. They are more than ten times as numerous here as in other regions of the Arctic (Remmert 1980). The main species in the Fugleberget catchment area include: Folsomia quadrioculata, Hypogastrura viatica, Onychiurus sp., Isotoma sp., and Anurida sp. (determined by Dr. M. Kaczmarek, Institute of Ecology, Polish Academy of Sciences; see also Stach 1962).

Chironomidae, the second largest insect group in the study area, occur in interstitial waters of moss sward and in small ponds. The dominant species are: Diamesa lindrothi, D. ursa, Cricotopus humeralis, Orhtocladius consobrinus, and Metriocnemus sp. (Styczyński \& Rakusa-Suszczewski 1963).

Acarina are also numerous and the main species include: Diapterobates notatus, Liochthonius sp., and Opiella translamellata (Seniczak 1978; Seniczak \& Plichta 1978).

The fauna of spiders and Enchytraeidae of the Hornsund region has not yet been elaborated.

Estimates of the number of individuals within each group of terrestrial microfauna in the Fugleberget catchment area for June show that in wet moss meadows there are $60,200,4700$, and 700 individuals per $\mathrm{m}^{2}$ of Collembola, Chironomidae and Acarina respectively. In the mixed meadows near the bird colonies 1200 individuals of Enchytraeidae per $\mathrm{m}^{2}$ were estimated (unpublished, preliminary data). All estimates were obtained using a direct counting method in samples of $100 \mathrm{~cm}^{3}$. Remmert (1980) has reported much higher numbers for the fauna of West Spitsbergen meadows, e.g. Collembola 243,500 and Acarina 22,000 individuals per $\mathrm{m}^{2}$. The large differences in estimates may result from climatic and trophic variations. Remmert studied the Isfjorden region where conditions for the flora and fauna are much better than in the Hornsund area. In addition, the higher dynamics of changes in numbers of tundra fauna may contribute to the discrepancy between the two data sets. For example, the numbers of Collembola in the Fugleberget catchment area doubled in the period 8 to 22 June, from 30,600 to 60,200 individuals per $\mathrm{m}^{2}$, and was probably still growing towards the late summer (detailed data are being elaborated). During the same period, numbers of Chironomidae larvae decreased from 4700 to 900 individuals per $\mathrm{m}^{2}$, with a major occurrence of pupae (1000 indi- 
viduals per $\mathrm{m}^{2}$ ) and adults (700 individuals per $\mathrm{m}^{2}$ ).

In the Fugleberget catchment area no herbivores were observed. A few species of Tardigrada can be suspected of sucking plant cells, though they can feed just as well by sucking on animals (Dastych, pers. comm.). Animals feeding on detritus and dead plant parts form the dominant group of tundra invertebrates, and these are protozoans, nematodes (Eudorylaimus carteri, $E$. maksymovi), rotifers, chironomid larvae, and several species of mites, Collembola, and Enchytraeidae. Animals feeding on the fungi and bacteria developing on dead plant material can be distinguished into a separate group of protozoans, possibly some rotifers, nematodes (e.g. Plectus parietinus, $P$. cirratus, Anoplectus porosus), and mites of the genera Scutobelba, Oppiella, and Nothrus. At the top of this small pyramid are the predators of nematodes (e.g. Prionchulus musca- rum, Labronema sp.), Tardigrada mentioned above, and spiders, the numbers of which are very low. Insectivorous birds, such as Calidris maritima, that nest in the Fugleberget catchment area in small numbers can be included as predators feeding on invertebrates. However, the role of birds in the energy flow through the tundra is not well understood.

\section{Catabolism of tundra microfauna}

In order to estimate the proportion of energy flowing through the section of tundra under study, scattered around due to catabolic processes, investigations into the metabolic rates of the dominant groups of microfauna were carried out. The results of the metabolic rates of protozoans, nematodes, rotifers, Tardigrada and insect larvae (Chironomidae) are given in Table 2, and the

Table 2. Metabolic rate in microfauna from Spitsbergen tundra site. Fugleberget catchment area. After Klekowski \& Opaliński in prep. a, b; Opaliński \& Klekowski in prep. a.

\begin{tabular}{|c|c|c|c|c|}
\hline \multirow[b]{2}{*}{ Taxon } & \multirow{2}{*}{$\begin{array}{l}\text { Wet wt } \\
\left(\mathrm{mg} \cdot 10^{-3}\right)\end{array}$} & \multicolumn{3}{|c|}{$\begin{array}{l}\text { Metabolic rate } \\
\left(\mathrm{mm}^{3} \cdot 10^{-3} \text { per } \mathrm{mg} 10^{-3} \text { per } \mathrm{h}\right)\end{array}$} \\
\hline & & $2^{\circ} \mathrm{C}$ & $6^{\circ} \mathrm{C}$ & $10^{\circ} \mathrm{C}$ \\
\hline \multicolumn{5}{|l|}{ Protozoa } \\
\hline Ciliata gen.sp. & 0.747 & 0.240 & - & - \\
\hline \multicolumn{5}{|l|}{ Rotatoria } \\
\hline Macrotrachela musculosa Milne & 1.36 & 0.222 & 0.331 & 0.619 \\
\hline Trichotria truncata (Whitelegge) & 21.73 & - & 0.103 & - \\
\hline \multicolumn{5}{|l|}{ Tardigrada } \\
\hline Doryphoribius smreczynskii Węglarska & 24.67 & 0.047 & 0.055 & 0.165 \\
\hline Diaphascon spitsbergensis (Richters) & 7.61 & 0.060 & - & - \\
\hline Macrobiotus islandicus Richters & 23.88 & - & 0.091 & - \\
\hline Macrobiotus echinogenitus (Richters) & 11.20 & - & 0.061 & - \\
\hline Macrobiotus harmsworthi Murray & 10.48 & - & 0.101 & - \\
\hline Macrobiotus spectabilis Thulin & 31.33 & - & 0.089 & - \\
\hline Macrobiotus dispar Murray & 39.10 & - & 0.073 & 0.129 \\
\hline \multicolumn{5}{|l|}{ Nematoda } \\
\hline Plectus parietinus Bastian & 5.35 & 0.180 & 0.274 & 0.432 \\
\hline Eudorylaimus carteri Bastian & 5.85 & 0.092 & 0.208 & 0.522 \\
\hline Plectus cirratus Bastian & 2.64 & 0.385 & 0.255 & - \\
\hline Anoplectus porosus Allen et Nottsinger & 7.99 & 0.039 & 0.094 & - \\
\hline Prionchulus muscarum (Dujardin) Wu et Hoeppli & 12.59 & - & 0.143 & - \\
\hline Eudorylaimus maksymovi Alther & 4.04 & - & 0.210 & - \\
\hline Labronema $\mathrm{sp}$. & 6.63 & - & 0.314 & - \\
\hline Tobrilus sp. & 14.69 & - & 0.153 & - \\
\hline \multicolumn{5}{|l|}{ Insecta } \\
\hline Chirononmidae spp. larvae & 114.0 & - & 0.286 & - \\
\hline \multicolumn{5}{|l|}{ Atanei* ${ }^{*}$} \\
\hline Conigerella borealis (Jacks.) & 297.0 & 0.063 & - & - \\
\hline Erigonidae gen. sp. juv. & 522.0 & - & $0.142^{* *}$ & - \\
\hline
\end{tabular}

* det. Dr. Wojciech Staręga, Zoological Institute, PAS, Warsaw

${ }^{* *}$ at $8^{\circ} \mathrm{C}$. 


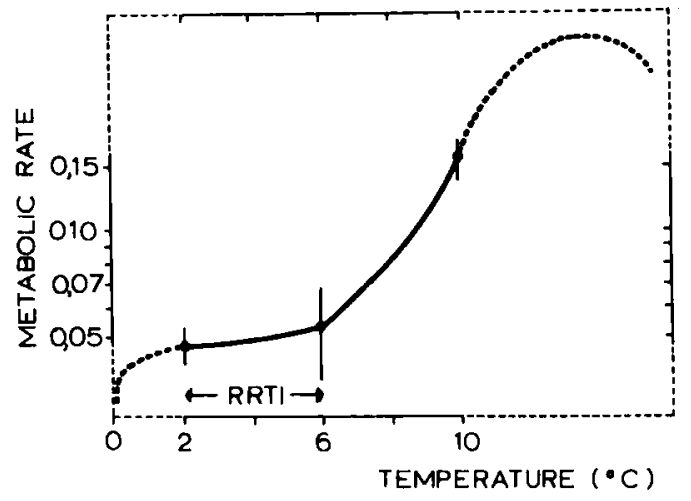

Fig. 5. Metabolic rate $\left(\mathrm{mm}^{3} \mathrm{O}_{2} \times 10^{-3}\right.$ per $\mathrm{g}$ wet wt. $\times 10^{-6}$ per hour) versus temperature in Doryphorybius smreczynskii (Tardigrada) from the Fugleberget catchment area, Spitsbergen. Solid line - measured range, dotted line - approximate range. RRTI - range of relative iemperature independence. Standard error of the means is added. (After Klekowski \& Opaliński in prep. b.)

results of Collembola, mites, and spiders are presently being elaborated. Measurements were taken using the method of Cartesian divers (ampulla divers, Zeuthen 1953) in a range of temperatures occurring in the natural habitat (at 2,6 , and $10^{\circ} \mathrm{C}$ ).

The lowest metabolic rate at $6^{\circ} \mathrm{C}$ was observed in Tardigrada (mean value for 6 species was $0.079 \mathrm{~mm}^{3} 10^{-3}$ per $\mathrm{mg} 10^{-3}$ per hour) and the highest in Chironomidae larvae with $0.286 \mathrm{~mm}^{3}$ $10^{-3}$ per $\mathrm{mg} 10^{-3}$ per hour. The mean metabolic rate in Rotatoria (2 species) and in Nematoda (8 species) was 0.217 and $0.206 \mathrm{~mm}^{3} 10^{-3}$ per $\mathrm{mg}$ $10^{-3}$ per hour respectively (Table 2 ).

The temperature optimum in some species of tundra microfauna lies within the range 2 to $6^{\circ} \mathrm{C}$, and further measurements at $2,4,5,8,10,12$, 14,18 , and $22^{\circ} \mathrm{C}$ confirm these results. At 2 to $6^{\circ} \mathrm{C}$ relative thermic independence, sensu Duncan \& Klekowski (1975), was observed, which is the lack of effect (or minimum effect) of temperature on the metabolic rate in animals (Fig. 5). The occurrence of a zone of relative thermic independence was observed in Macrotrachela musculosa (rotifer), Doryphoribius smreczynskii (Tardigrada), and Plectus parietinus (nematode).

Although during the summer moss swards and soil surface may be heated to a temperature above $10^{\circ} \mathrm{C}$, the temperature optimum for the tundra microfauna is very narrow - about $4^{\circ} \mathrm{C}$. It is probable that these animals can migrate within a several $\mathrm{cm}$ thick layer of moss or soil seeking the optimum thermal conditions.
Owing to insufficient information available on the metabolic rates of rotifers and Tardigrada derived from natural conditions, as opposed to laboratory culture, it is difficult to compare the metabolic rate of these animals living in the Arctic with that of corresponding species in the temperate zone. However, even approximate data indicate that the metabolism of arctic animals is higher (sometimes by several orders of magnitude) compared to animals of the temperate zone (Klekowski \& Opaliński in prep. b). This would confirm the contention that metabolic cold compensation occurs in at least some arctic animals.

\section{Matter flow and energy cycling in ornithogenic tundra}

In the Fugleberget area, the organic matter inflow and high primary production do not affect the formation of soils and the development of the level of reducers. The plant biomass produced is not consumed in a 'live state', since the herbivore level practically does not exist in the 'grazing food chain', which thus cannot function. At the end of the vegetative season the green parts of the plants die down and in the following season form dead plant material. During the subsequent three to five years a slow destruction of the dead plant material causes only small changes in the outer structures of the plant, as is clearly visible in mosses. Biochemical microbiological decomposition of this material is very slow. This can be inferred not only from the chemical composition of dead plant organic matter exposed for many years in the tundra (Opaliński in prep.), but also from the very low numbers and the activity of bacteria, fungi, and Actinomycetes in the soil (Zabawski \& Żurawska 1975).

Dead plant material and the detritus originating thereof is a food supply for the microflora and detritivores. The microflora becomes in turn the food supply for fungi and bacteriophages ('ivora'), and fungi, together with detritivores, become food for predators.

The major part of the dead plant matter is converted into dissolved detritus matter during the years following its production and is in this form carried out of the system to the sea by the waters of the catchment area. A smaller portion of the detritus is possibly deposited in a small lake with a surface area of about 0.25 ha (see Fig. 4) situated within the catchment area. Doroszewski 


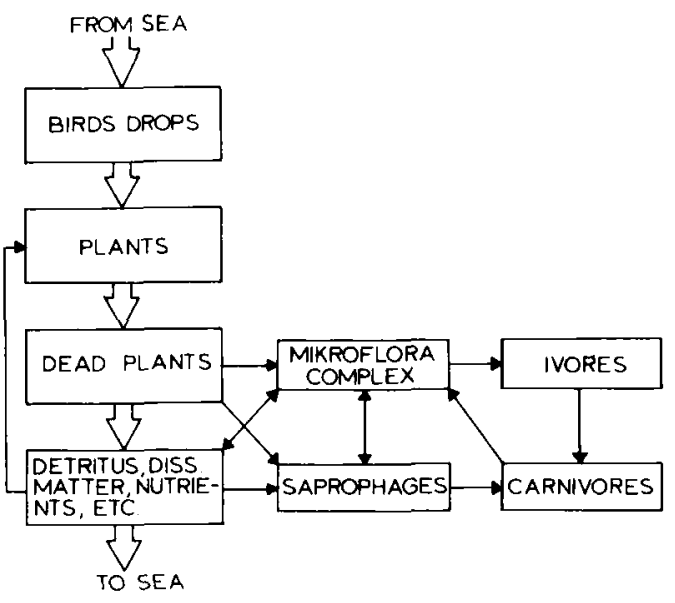

Fig. 6. Matter flow scheme in ornithogenic tundra ecosystem of the Fugleberget catchment area. Boxes - standing crops, arrows - matter flow direction (not to scale).

(1958) has drawn attention to the small tundra lakes as sites for the accumulation of organic matter. There were no large deposits of dead organic matter and detritus (e.g. turf deposits) observed within the catchment area (Pękala pers. comm.), although in the adjacent tundra in the region of Hornsund, which has different spacial and hydrological configurations, such deposits do occur (Klementowski 1977). Hence, in the Fugleberget catchment area, one can speak of flow rather than matter cycling in the tundra (Fig. 6). Matter cycling proper occurs in the macroscale of the tundra/sea system and the factor that triggers the movement of the 'machinery', the matter cycling, and the energy flow are sea birds nesting on land and feeding in coastal waters.

\section{Summary}

The present paper contains the results of the first stage of investigations carried out in the Fugleberget catchment area of the Hornsund fjord region on Spitsbergen. The aim of these studies was to learn about the structure and function of the ornithogenic tundra typical for this region, and to elaborate on the function of this type of ecosystem.

The tundra within the Fugleberget catchment area is supplied with allochthonous organic matter and nutrients originating in the nesting rookeries of little auks (Plautus alle). The allochthonous matter (bird faeces) is distributed in the tundra by surface waters, and it results in the development of plant associations that cover from 5\% to $100 \%$ of the soil surface. The plant/soil associations dominant in the study area are lichen associations covering $53 \%$ of the catchment area. The wet moss meadows, dry mixed meadows, and dry meadows are most productive.

The primary production of plant associations of the Fugleberget catchment area is high, and in the wet moss meadows it is $270 \mathrm{~g}$ dry wt $\mathrm{m}^{-2}$ year $^{-1}$. The productivity is higher than in other tundra ecosystems which are not supplied with nutrients from the outside.

The destructive processes in plant biomass during the vegetative season are very slow. They are of a mechanical rather than biological character, which is connected to the small activity of soil microfauna.

The fauna of the tundra invertebrates of the Fugleberget catchment area is very poor. This is consistent with the rest of Spitsbergen. The invertebrate fauna comprises Protozoa, Nematoda, Rotatoria, Tardigrada, Collembola, Acarina, Arachnoidea, Insecta (Diptera), and a few Crustacea and Enchytraeidae. Herbivorous animals are lacking in the invertebrate fauna, and detritivores are the most abundant group, followed by bacteriophages and predators.

After the vegetative season the main part of the plant biomass produced becomes dead plant material, which is utilized by detritivores and by the complex of soil microfauna only to a minimum extent. The gross of this material is converted into detritus, dissolved organic matter, etc. and in this form passes out of the system into the sea. The outflow of detritus from the system is via running surface waters. Thus, in the case of the Fugleberget catchment area, there is a flow of matter rather than matter cycling. The tundra/ sea system shows the large scale circulation of matter, and marine birds are a factor triggering this circulation.

Acknowledgements. - The authors wish to thank sincerely colleagues who have identified animals used for the metabolic rate measurements: Prof. Dr. Henryk Klimowicz of the Institute of Environment Management in Warsaw (Rotatoria), Dr. Lucyna Wasilewska (Nematoda) and Dr. Maria Kaczmarek (Collembola) of the Institute of Ecology PAS at Dziekanów Leśny, and Dr. Hieronim Dastych of the Adam Mickiewisz University in Poznań (Tardigrada).

We also wish to give our heartfelt thanks to the Institute of Geophysics PAS in Warsaw, hosts of the Polish Polar Station in Hornsund, Spitsbergen, for enabling us to carry out this research. We are also grateful to the participants of the Polish 
expedition to Spitsbergen who overwintered during the season 1979/1980 under the leadership of Professor Marian Pulina and during the season 1981/1982 under the leadership of Dr. Witold Mizerski, who welcomed us in Hornsund in the spring of 1980 and 1982 with their kind assistance and understanding of our field and laboratory studies.

\section{References}

Baker, J. H. 1972. The rate of production and decomposition of Chrisodentium aciphyllum (Hook, F. and Wils.) Broth. Brit. Antarct. Surv. Bull. 27, 123-129.

Baranowski, S. 1975: The climate of West Spitsbergen in the light of material obtained from Isfjord Radio and Hornsund. Acta Univ. Wratislaviensis 251, 21-34.

Belopolsky, L. O. 1957: Ekologia morskich kolonialnych ptic Barencovo morja (Ecology of colony-forming birds of the Barents Sea). Nauka, Moskva, 460 pp. (in Russian).

Billings, W. D. 1973: Arctic and Alpine vegetation: Similarities, differences and susceptibility to distribuance. Bio Science 23, 697-704

Birkenmajer, K. \& Skreslet, S. 1963: Breeding colony of Ivory Gulls in Torrell Land, Vestspitsbergen. Norsk Polarinstitutt Árbok 1962, 120-126.

Bliss, I. C. 1975: Devon Island, Canada. Pp. 17-60 in Rosswall, T. \& Heal, O. W. (eds.): Structure and function of tundra ecosystems. Swedish Natural Science Research Council, Stockholm. Ecol. Bull. 20.

Bliss, I. C., Courtin, G. M., Pattie, D. L., Riewe, R. R., Whitefield, D. W. A. \& Widden, P. 1973: Arctic tundra ecosystem. Ann. Rev. Ecol. Syst. 4, 359-399.

Brown, J. 1975: Ecological investigation of the tundra biome in the Prudhoe Bay Region, Alaska. Biol. Pap. Univ. Alaska, Spec. Rep., 1-215.

Brzoska, W. 1976: Produktivität und Energiegehalte von Getosspflanzen in Adventdalen (Spitsbergen). Oecologia 22, 387-398.

Bunnell, F. L., MacLean, S. F. jr. \& Brown, J. 1975: Barrow, Alaska, USA. Pp. 73-124 in Rosswall, T. \& Heal, O. W. (eds.): Structure and function of tundra ecosystems. Swedish Natural Science Research Council, Stockholm. Ecol. Bull. 20.

Doroszewski, M. 1958: Z badań nad pierwothiakami Hornsundu (About studies on Hornsund Protozoa). Przegl. Geofiz. 3, 187-189 (Engl. summ.).

Doroszewski, M. 1959: Paramecium arcticum sp. nov. Bull. Acad. Polon. Sci. Ser. Sci. Biol. 7, 73-78.

Duncan, A. \& Klekowski, R. Z. 1975: Parameters of an energy budget. Pp. 97-147 in Grodziński, W., Klekowski, R. Z. \& Duncan, A. (eds.): Methods for ecological bioenergetics. IBP Handbook 24.

Eurola, S. 1968: Über die Fjeletheidervegetation in den Gebiete von Isfjorden und Hornsund in West Spitsbergen. Aquilo, Ser. Bot. 7, 1-56.

Eurola, S. \& Hakala, U. K. 1977: The bird cliff vegetation of Svalbard. Aquilo, Ser. Bot. 15, 1-18.

Fabiszewski, J. 1967: Torfoznawcze i botaniczne badania w tundrze spitsbergeńskiej (Peat bog and botanical studies in Spitsbergen tundra). Spraw. Wroct. Tow. Nauk. 29, 58-60 (in Polish).

Ferens, B. 1960: Bird notes from Spitsbergen, Summer 1957. Proc. XII int. Ornith. Congr. Helsinki 1958, 209-212.
French, D. D. 1974: Classification of IBP tundra biome sites based on climate and soil properties. Pp. 3-25 in Holding, A. J., Heal, O. W. \& Flanagan, P. W. (eds.): Soil organisms and decomposition in tundra. Tundra Biome Steering Commintee, Stockholm.

Karczmarz, K. 1966: Calliergon obtusifolium sp. nov. - une espece nouvelle du genère Calliergon (Sull.) Kindb. Rev. Bryol. Lichenol. 34, 762-764.

Karczmarz, K. 1971: A monograph of the genus Calliergon (Sull.) Kindb. Monogr. Bot. 34, 1-208.

Karczmarz, K. \& Kuc, M. 1966: Notes on Calliergon orbicularicordatum from Spitsbergen. The Bryologist 69, 373-376.

Klekowski, R. Z. \& Opaliński, K. W. in prep. a: Oxygen consumption in Nematodes from the Hornsund Region. Pol. Polar Res.

Klekowski, R. Z. \& Opaliński, K. W. in prep. b: Oxygen consumption in some Tartigrada species from the Hornsund area. Pol. Polar Res.

Klekowski, R. Z. \& Opaliński, K. W. in prep. c: Oxygen consumption in Acari from Spitsbergen tundra. Pol. Polar Res.

Klementowski, J. 1977: Morfologia torfowisk SW Spitsbergenu (Morphology of SW Spitsbergen peat bogs). Pp. 59-64 in Polska Wyprawa Spitsbergeńska w 1974 r. Uniwersytet Wrocławski, Wrocław (in Polish).

Krawczyk, W. \& Pulina, M. 1982: Wstępne wyniki badań hydrologicznych i hydrochemicznych w zlewni Fugleberget (SW Spitsbergen) (Preliminary report on hydrological and hydrochemical studies on the Fugleberget catchment area, SW Spitsbergen). Pp. 167-180 in Wyprawy polarne Uniwersytetu Slgskiego 1977-1980, 1. Uniwersytet Slaski, Katowice (in Polish).

Krzyszowska, A. in prep.: Hydrology of surface waters and nutrients dynamics in the Fugleberget catchment area (Spitsbergen). Pol. Polar Res.

Krzyszowska, A., Pękala, K. \& Pereyma, J. in prep.: Physiographic and geographic description of the Fugleberget catchment area (Spitsbergen). Pol. Polar Res.

Kuc, M. 1963: Flora of mosses and their distribution on the north coast of Hornsund (SW Svalbard). Frag. Flor. Geobot. 9, 291-366.

Kuc, M. 1968: Phenological spectrum of vegetation on the north coast of Hornsund, Vestspitsbergen. Pp. 117-118 in Birkenmajer, K. (ed.): Pol. Spitsbergen Exped. 1957-1960. Pol. Acad. Sci., Warszawa.

Matveeva, N. V., Darinkina, M. O. \& Chernov, Yu. I. 1975: Maria Pronchitsheva Bay, USSR. Pp. 61-72 in Rosswall, T. \& Heal, C. W. (eds.): Structure and function of tundra ecosystems. Swedish Natural Sciences Research Council, Stockholm. Ecol. Bull. 20.

Mizerski, W. in prep.: The use of geodetic methods in ecological investigations in Spitsbergen tundra. Pol. Polar Res.

Niedbała, W. 1971: Oribatei (Acari) of Spitsbergen. Bull. Acad. Pol. Asci. 11, 737-742.

Norderhaug, M. 1970: The rolc of the little auk, Plautus alle (L.), in Arctic ecosystems. Pp. 558-560 in Holdgate, M. W. (ed.): Antarctic Ecology vol. I. Academic Press, London, New York.

Nowak, J. 1965: The lichens from Hornsund (SW Spitsbergen) collected during the Polish Polar Expeditions in 1957 and 1958. Frag. Flor. Geobot. 11, 171-190.

Nowak, J. 1968: Lichens of Hornsund, Vestspitsbergen. Pp. 109-112 in Birkenmajer, K. (ed.): Pol. Spitsbergen Exped. 1957-1960. Pol. Acad. Sci., Warszawa. 
Olech, M. \& Dubiel, E. in prep.: Plant communities associated with bird colonies in the Fugleberget area (Spitsbergen). Pol. Polar Res.

Opaliniski, K. W. in prep.: Primary production and destruction in Spitsbergen ornithogenous tundra site. Pol. Polar Res.

Opaliński, K. W. \& Klekowski, R. Z. in prep. a: Oxygen consumption in Macrotrachela musculosa Milne 1886 (Rotatoria) from High Arctic. Pol. Polar Res.

Opaliński, K. W. \& Klekowski, R. Z. in prep. b: The dependence between temperature and oxygen consumption in Spitsbergen Collembola. Pol. Polar Res.

Plichta, W. 1977: Systematics of soils of the Hornsund region, West Spitsbergen. Acta Univ. Nicolai Copernici 43, 175-180.

Pulina, M. in prep.: Water balance and hydrochemistry of surface waters in the Fugleberget catchment area (Spitsbergen). Pol. Polar Res.

Pulina, M., Krawczyk, W. \& Pereyma, J. 1984: Water balance and chemical denudation in the unglaciated Fugleberget basin (SW Spitsbergen). Pol. Polar Res. 5, 183-205.

Rakusa-Suszczewski, S. \& Styczyński, B. 1968: Tendipedidae of selected fresh water habitats in the Hornsund region, Vestspitsbergen. Pp. 151-158 in Birkenmajer, K. (ed.): Polish Spitsbergen Expeditions 1957-1960. Pol. Acad. Sci., Warszawa.

Remmert, H. 1980: Arctic Animal Ecology. Springer Verlag, Berlin, Heidelberg. New York. 250 pp.

Røen. U. I, 1962: Studies on freshwater entomonstraca in Greenland. II. Localities, ecology, and geographical distribution of the species. Medd. om Grønland 170, 1-249.

Rosswall, T. \& Heal, O. W. 1975: The IBP Tundra Biome an introduction. Pp. 7-16 in Structure and function of tundra ecosystems. Swedish Natural Science Research Council, Stockholm. Ecol. Bull. 20.

Rüppell, G. 1968: Über Oekologie und Tagesrythmus von Boden-arthropoden eutrophierter Tundragebiete Westspitzbergens. Pedobiologia 8, 150-157.

Sater. J. W., Rondhovde, A. G. \& von Allen, L. C. 1971: Arctic environment and resources. The Arctic Institute of North America, Washington D.C.

Seniczak, S. 1978: Stadia mtodociane mechowców (Acari, Oribatei). (Juvenile stages of moss mites (Acarina, Oribatei) as an essential component of agglomerations of these mites transforming the organic matter of soil.) Uniwersytet im. Nikołaja Kopernika, Toruń. 171 pp. (Engl. Summ.).

Seniczak, S. \& Plichta. W. 1978: Structural dependence of moss mite populations (Acari, Oribatei) on patchiness of vegetation in moss-lichen tundra at the north coast of Hornsund, West Spitsbergen. Pedobiologia 18, 145-152.

Skirgiełło, A. 1961: De quelques champignons superieur recoltés par M. Kuc au Spitsbergen en 1958. Bull. Res. Counc. Israel. Sect. d. Botany 19, 287-293.

Skirgiello, A. 1968: Higher fungi collected in 1958 at Hornsund, Westspitsbergen. Pp. 113-117 in Birkenmajer, K. (ed.): Pol. Spitsbergen Exp. 1957-1960. Pol. Acad. Sci., Warszawa

Srodoń, A. 1968: A survey of botanical and paleobotanical research of the Polish Spitsbergen Expeditions 1957-1958.
Pp. 91-96 in Birkenmajer, K. (ed.): Pol. Spitsbergen Exp. 1957-1960. Pol. Acad. Sci., Warszawa.

Stach, J. 1962: On the fauna of Collembola from Spitsbergen. Acra Zool. Cracov. 7, 1-20.

Stempniewicz, L. 1981: Breeding biology of the little auk in Hornsund, Spitsbergen. Acta Ornith. 18, 141-165.

Stempniewicz, L. in prep.: Ecology and role in ornithocoprophilus effect formation of little auks (Plautus alle) in Spitsbergen coastal tundra. Pol. Polar Res.

Styczyński, B.\& Rakusa-Suszczewski, S.1963: Tendipedidae of selected water habitats of the Hornsund region (Spitsbergen). Pol. Arch. Hydrobiol. 11, 327-342.

Summerhayes, V. S. \& Elton, C. 1923: Contributions to the ecology of Spitsbergen and Bear Island. J. Ecol. 11, 214-286.

Summerhayes, V. S. \& Elton, C. 1928: Further contributions to the ecology of Spitsbergen. J. Ecol. 16, 193-268.

Svensson, R. H. \& Rosswall, T. 1980: Energy flow through the Subarctic mire at Stordalen. Pp. 283-301 in Sonesson, M. (ed.): Ecology of a Subarctic mire. Swedish Natural Science Research Council, Stockholm. Ecol. Bull. 30.

Swift, M. J., Heal, O. W. \& Anderson, M. J. 1979: Decomposition in terrestrial ecosystems. Blackwell, Oxford, London, Edinburgh, Melbourne. 372 pp.

Syroechkovsky, E. E. 1958: Rol zivotnych v obrazovanii pervicnych pocv $\mathrm{v}$ usloviach poliarnoi oblasti zemhogo sara (na primere Antarktiki) (Animals' role in primitive soil formation in polar regions on the Antarctic example). Zool. Z. 38, $1770-1775$ (in Russian).

Szerszeń, L. 1965: Studia nad glebami strefy klimatu arktycznego na przykladzie południowo-zachodniego Spitsbergenu (Studies on soils of Arctic climate zone on the example of Southwest Spitsbergen). Zesz. Nauk. Wyż. Szk. Rol. we Wrociawiu, Rolnictwo 19, 39-97 (Engl. summ.).

Tatur, A. \& Barczuk, A. 1984: Phosphates of ornithogenic soils on the volcanic King George Island. (Maritime Antarctic). Pol. Polar Res 5, 31-60.

Tieszen, L. L. 1972: The seasonal course of above ground productivity and chlorophyll distribution in a wet Arctic tundra at Barrow, Alaska. Arct. Alp. Res. 4, 307-324.

Uchmański, J., Klekowski, R. Z. \& Opaliński, K. W. in prep.: Mathematical model of functioning of Spitsbergen ornithogenous tundra ecosystem. Pol. Polar Res.

Weglarska. B. 1966: Die Tardigraden (Tardigrada) Spitsbergens. Acta Zool. Cracov. 1I, 43-51.

Wielgolaski, F. E. 1972: Vegetation types and primary production in tundra. Pp. 9-34 in Wielgolaski, F. E. \& Rosswall, T. (eds.): Tundra biome. Tundra Biome Steering Committee, Stockholm.

Zabawski, J. \& Żurawska, M. 1975: Mikroflora pierwotnych gleb rejonu Hornsundu i lodowca Werenskiolda (Zachodni Spitsbergen). Polskie Wyprawy na Spitsbergen 1972 i 1973 r. (The microflora of primitive soils at Hornsund and Werenskiold Glacier regions, West Spitsbergen). Pp. 101-108 in Wydawnictwa Uniwersytetu Wroctawskiego, Wroctaw (in Polish).

Zeuthen, E. 1953: Oxygen uptake as related to body size in organisms. Quart. Rev. Biol. 28, 1-12. 